\title{
Identification of Pathogenic Strains within Serogroups of Yersinia pseudotuberculosis and the Presence of Non-Pathogenic Strains Isolated from Animals and the Environment
}

\author{
Tetsuji NAGANO, Tomoko KIYOHARA ${ }^{1)}$, Kiyomi SUZUKI ${ }^{1}$, Misao TSUBOKURA ${ }^{1)}$, and Koichi OTSUKI* \\ Departments of Veterinary Public Health, and ${ }^{1}$ Veterinary Microbiology, Faculty of Agriculture, Tottori University, Tottori 680, Japan
}

(Received 14 October 1996/Accepted 25 November 1996)

\begin{abstract}
The existence of apathogenic strains of Yersinia pseudotuberculosis (Yp) has not so far been reported. Recently, the authors characterized new serogroups and a new subgroup in $\mathrm{Yp}$, that is, O9, O10, O12, O13, O14 and O1c, and the pathogenicity of these new strains was of interest. A total of 137 strains of serogroups O1c, O6, O7, O9, O10, O11, O12, O13 and O14 of Yp were investigated for their pathogenicity in vivo and in vitro. Although catalase activity and the inv gene were detected in all strains except those of groups O13 and O14, only a few strains, from serogroups O6 and O10 caused severe infection in mice. The remaining strains caused no mortality or severe infection even when they grew in limited tissues of infected mice. All the strains of Yp not possessing the virulence plasmid $\mathrm{pYV}$ caused no severe infection in mice. It is evident that less pathogenic Yp exists and that not only pathogenic but also less pathogenic Yp organisms exist in the same serogroup. - KEY WORDS: new serogroup, non-pathogenic strain, Yersinia pseudotuberculosis.
\end{abstract}

J. Vet. Med.Sci. 59(3): 153-158, 1997

Yersinia pseudotuberculosis has been classified into serogroups O1 to O8 [12-14, 19, 23, 26]. Recently, new serogroups O9, O10, O11 and a new subgroup O1c were added by Tsubokura and Aleksic [24]. Bacteria belonging to these serogroups were not isolated from diseased animals and patients but from wild rats, racoon dogs and mountain water [24]. More recently, further serogroups, designated $\mathrm{O} 12$, $\mathrm{O} 13$ and $\mathrm{O} 14$, were added by the present authors [in press]. Yersinia enterocolitica has been classified into 27 O-serogroups and 5 biotypes [2, 29, 30]. It is well known that the serogroup and biotype of pathogenic $Y$. enterocolitica strains are limited and most non-pathogenic strains of $Y$. enterocolitica has been isolated from wild animals and the environment [30,31]. Numerous strains of $Y$. pseudotuberculosis which belong to serogroups $\mathrm{O} 1$ to $\mathrm{O} 5$ have been isolated in Europe and Japan and almost all of them are pathogenic $[12,13,19,23,25,27]$. There are several reports on the virulence factors of $Y$. pseudotuberculosis, however only limited information on non-pathogenic strains. Tsubokura et al. isolated an avirulent strain of $Y$. pseudotuberculosis $\mathrm{O} 3$ from swine which does not ferment melibiose [25]. The relationships between pathogenicity and serological and biochemical properties of $Y$. pseudotuberculosis have been poorly characterized. It is possible that avirulent $Y$. pseudotuberculosis strains as well as $Y$. enterocolitica are isolated from humans, animals and/or the environment. We were interested to survey avirulent strains of $Y$. pseudotuberculosis. In the present investigation, newly serogrouped strains of $Y$. pseudotuberculosis were examined for their pathogenicity in vivo and in vitro since some of

* Correspondence to: Otsuki, K., Department of Veterinary Pubic Health, Faculty of Agriculture, Tottori University, 4101 Koyama Minami, Tottori 680, Japan. them were not isolated from patient or diseased animals, but from apparently healthy free-living animals and the environment.

\section{MATERIALS AND METHODS}

The strains of $Y$. pseudotuberculosis used in this investigation are listed in Table 1 . The in vitro tests to select avirulent strains of $Y$. pseudotuberculosis were performed as follows. An auto-agglutination test at $37^{\circ} \mathrm{C}$ was done by the method of Laird and Cavanaugh [14] modified using MR-VP medium (Difco Laboratories, Detroit, Mich.). The calcium dependent test at $37^{\circ} \mathrm{C}$ was carried out on magnesium oxalate agar: trypticase soy agar plate supplemented with $20 \mathrm{mM}$ sodium oxalate and $20 \mathrm{mM}$ magnesium chloride [8]. Pyrazinamidase activity was tested by the method of Kandolo and Wauters [10]. Catalase activity was detected on trypticase soy slant agar (BBL, Microbiology Systems, Cockeysville, Md.) [1]. After incubation for $48 \mathrm{hr}$ at $25^{\circ} \mathrm{C}$ or $37^{\circ} \mathrm{C}$, one milliliter of a $3 \%$ hydrogen peroxide solution was flooded onto the slant. The tubes generating a considerable amount of oxygen were recorded as catalase-positive. Possession of plasmid was identified by the alkaline lysis technique of Kaneko et al. [11], followed by agarose gel electrophoresis for $0.5 \mathrm{hr}$ at $100 \mathrm{~V}$ on a $0.7 \%$ horizontal agarose gel in Tris-borate buffer. Restriction endonuclease analysis of plasmid DNA was carried out with BamHI [11]. Detection of virF gene encoded in plasmid DNA and of inv gene encoded by chromosomal DNA as a virulence-associated gene, was performed with the polymerase chain reaction (PCR) method described by Nakajima et al. [16]. The primers for the virF gene and inv gene were obtained from Dr. H. Nakajima (Okayama Prefecture Institute for Environmental Science and Public Health, Okayama, Japan). 
Table 1. The strain used

\begin{tabular}{crl}
\hline Serogroup & No. of strain & Source \\
\hline $1 \mathrm{c}$ & 2 & Wild-living small rodent, mountain water \\
6 & 45 & Dog, racoon dog, guinea pig, wild-living small rodent, mountain water \\
7 & 46 & Dog, racoon dog, wild-living small rodent, mountain water \\
9 & 14 & Wild-living small rodent, mountain water \\
10 & 16 & Racoon dog, mountain water, chicken \\
11 & 7 & Mole, wild-living small rodent, mountain water \\
12 & 4 & Mountain water \\
13 & 2 & Wild-living small rodent \\
14 & 1 & Wild-living small rodent \\
\hline
\end{tabular}

Pathogenicity for mice was also examined. Briefly, groups of five ICR mice (female, 4 weeks old) deprived of water for $18 \mathrm{hr}$ were allowed to drink freely $25 \mathrm{ml}$ of water containing $10^{9} \mathrm{cfu} / \mathrm{ml}$ of one of the bacterial strains. Infected mice were observed for clinical signs and for recovery of bacteria from 1 to 12 days post inoculation (p.i.). The mice that died during the experimental period were autopsied immediately, survivors were killed and autopsied at 12 days p.i. The lung, liver, spleen, kidney, mesenteric lymph nodes and intestine were removed from each mouse, plated on CIN agar plate (Difco Laboratories, Detroit, Mich.) and incubated at $25^{\circ} \mathrm{C}$. Colonies were counted in $48 \mathrm{hr}$ p.i.

\section{RESULTS}

Detection of virulence-associated properties among $Y$. pseudotuberculosis of different serogroups: The results obtained are summarized in Table 2. A few strains belonging to serogroups O1c, O6, O7, O10, O12 and $\mathrm{O} 14$ were positive in the auto-agglutination test; a few strains belonging to serogroups $\mathrm{O6}, \mathrm{O} 7$ and $\mathrm{O} 10$ showed calcium dependency; all strains except $\mathrm{O} 13$ and $\mathrm{O} 14$ ones showed catalase activity. Some strains belonging to $\mathrm{O} 6$ and $\mathrm{O} 10$

Table 2. Patterns of virulence-associated properties with serogroups of Y. pseudotuberculosis

\begin{tabular}{|c|c|c|c|c|c|c|c|c|c|}
\hline Serogroup & $\mathrm{AA}^{\mathrm{a})}$ & $\mathrm{Ca}^{2+b)}$ & $\mathrm{PZ}^{\mathrm{c})}$ & $\mathrm{Cat}^{\mathrm{d})}$ & pYV $\left.{ }^{e}\right)$ & $i n v^{\mathrm{f})}$ & $\operatorname{vir} F^{\mathrm{g})}$ & Mouse $^{\text {h) }}$ & No. of strain \\
\hline \multirow[t]{2}{*}{$1 \mathrm{c}$} & + & - & + & + & - & + & - & - & 1 \\
\hline & + & - & - & + & - & + & - & - & 1 \\
\hline \multirow[t]{3}{*}{6} & + & + & (i) & + & + & + & + & + & 3 \\
\hline & + & $\mathrm{D}^{\mathrm{i})}$ & $\mathrm{d}$ & + & - & + & - & - & 5 \\
\hline & - & - & + & + & - & + & - & - & 37 \\
\hline \multirow[t]{3}{*}{7} & + & + & - & + & - & $\mathrm{NT}^{\mathrm{k})}$ & NT & NT & 1 \\
\hline & - & + & D & + & - & + & - & - & 29 \\
\hline & - & - & $\mathrm{D}$ & + & - & + & - & - & 16 \\
\hline 9 & - & - & + & + & - & + & - & - & 14 \\
\hline \multirow[t]{2}{*}{10} & + & $\mathrm{D}$ & - & + & + & + & + & + & 4 \\
\hline & - & $\mathrm{D}$ & - & + & + & + & + & + & 9 \\
\hline- & - & + & + & - & + & - & NT & 3 & \\
\hline 11 & - & - & D & + & - & + & - & - & 7 \\
\hline 12 & d & - & d & + & - & + & - & - & 4 \\
\hline 13 & - & - & - & - & - & + & - & - & 2 \\
\hline 14 & + & - & - & - & - & + & - & - & 1 \\
\hline
\end{tabular}

a) AA; auto-agglutination. b) $\mathrm{Ca}^{2+}$; calcium dependence. c) $\mathrm{PZ}$; pyrazinamidase activity d) Cat; catalase activity. e) pYV; presence of virulence plasmid. f) inv; presence of inv gene. g) virF; presence of $\operatorname{vir} F$ gene, h) Mouse; virulence to mice. i) d; negatives were majority. j) D; positives were majority. k) NT; not tested. 


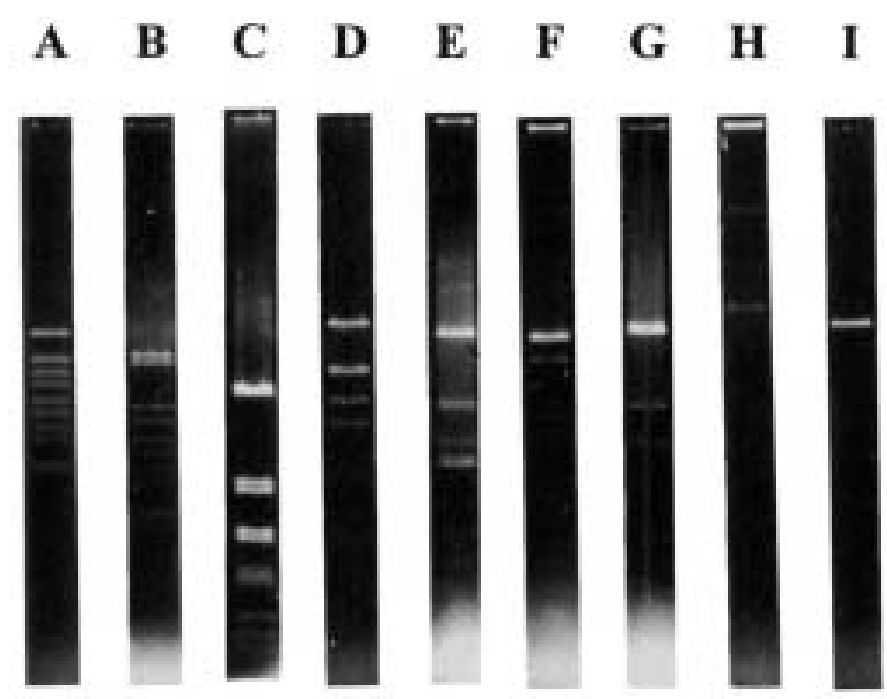

Serogroup

\begin{tabular}{cccccccccc} 
& & & & & & & & & Total \\
2 & & & & & & 1 & & & 1 \\
& & & 12 & & 1 & 1 & 1 & 4 & 21 \\
& & 4 & 20 & 1 & & 4 & & 2 & 31 \\
& & & & & 7 & & & 7 \\
& 13 & & & & & & & & 13 \\
& & & 1 & & & 1 & & & 2 \\
\hline 2 & 13 & 4 & 33 & 1 & 1 & 14 & 1 & 6 & 75 \\
\hline
\end{tabular}

Fig. 1. Restriction endonuclease BamHI assay of plasmids from Y. pseudotuberculosis O1c, O6, O7, O9, $\mathrm{O} 10$ and $\mathrm{O} 11$.

possessed the virulence-associated factors.

Plasmid DNA in different serogroups of $Y$. pseudotuberculosis: Most strains investigated possessed plasmids, however the virulence plasmid was detected only in a few O6 and O10 strains (data not shown). The restriction endonuclease assay of plasmid DNA with BamHI (Fig. 1) gave patterns that divided the strains into 9 types, type A to type I. Type D was most prevalent and type $\mathrm{G}$ was detected in all serogroups tested except O10. Types A and $\mathrm{B}$ had identical patterns of virulence plasmid whereas type $\mathrm{C}$ to type I had non-pathogenic patterns (Fig. 1). The gene virF was detected in the strains which harbored pYV from groups $\mathrm{O} 6$ and $\mathrm{O} 10$. The $i n v$ gene was demonstrated in the strains of all serogroups in the PCR test (Table 2 and Fig. 2).

Pathogenicity of Y. pseudotuberculosis for mice: Pathogenicity of $Y$. pseudotuberculosis for mice was calculated by investigating mortality and multiplication of bacteria in the intestine and other organs. We considered a strain of $Y$. pseudotuberculosis as pathogenic for mice when more than $10^{7} \mathrm{cfu} / \mathrm{g}$ of bacteria was continually recovered from feces throughout this investigation and the bacteria were recovered from other organs at 12 days p.i. A few strains of serogroups O6 and O10 were lethal for mice. These strains grew in the intestine of infected mice and high numbers of bacteria were recovered from feces throughout the experiment. Moreover, the spleens were enlarged and many different-sized grayish-white foci were present in the spleen and the liver. Large numbers of bacteria were recovered from the lung, liver, spleen and kidney of infected mice. While, in mice inoculated with strains of serogroups O1c, O6, O7, O9, O11 and O12, the number of bacteria recovered from the feces gradually decreased, and in most mice no macroscopic lesions were seen in any organs, except from some of the mesenteric lymph nodes. No infecting bacteria were recovered from these organs. The duration of excretion of strains of $\mathrm{O} 1 \mathrm{c}$ and $\mathrm{O} 9$ was less than that of other serogroups. Few bacteria belonging to serogroups $\mathrm{O} 13$ and $\mathrm{O} 14$ were recovered from feces of inoculated mice at 2 days p.i. (Table 3 ).

Summary of the pathogenicity of different serogroups of Y. pseudotuberculosis: The pathogenicity of different serogroups of $Y$. pseudotuberculosis was investigated (Table 4). The pathogenicity of strains of serogroups $\mathrm{O} 1$ to O5 was not examined in this study, as they have been isolated from patients and their pathogenicity has already been 


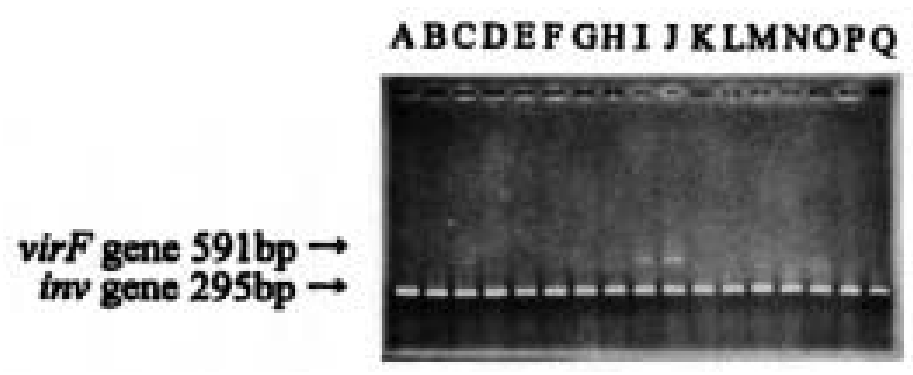

Fig. 2. Detection of virF gene and inv gene from $Y$. pseudotuberculosis by polymerase chain reaction. AandB, O1c; CandD, O6; EandF, O7; GandH, O9; IandJ, O10; KandL, O11; MandN, O12; OandP, O13; Q, O14.

Table 3. Comparison of mouse pathogenicity with serogroups of $Y$. pseudotuberculosis

\begin{tabular}{cccc}
\hline Serogroup & Colonization of intestine & Propagation in organ & Lethality \\
\hline $1 \mathrm{c}$ & + & - & - \\
& - & - & - \\
6 & + & + & + \\
& + & - & - \\
7 & + & + & - \\
& + & - & - \\
9 & - & - & - \\
10 & + & + & + \\
& + & + & + \\
11 & + & - & - \\
12 & + & - & - \\
13 & - & - & - \\
14 & - & - & - \\
\hline
\end{tabular}

Table 4. Pathogenicity of $Y$. pseudotuberculosis with serogroups

\begin{tabular}{|c|c|c|}
\hline \multicolumn{2}{|c|}{ Serogroup } & \multirow{2}{*}{$\frac{\text { Pathogenicity }}{+}$} \\
\hline 1 & $1 \mathrm{a}$ & \\
\hline & $1 b$ & + \\
\hline & $1 \mathrm{c}$ & - \\
\hline \multirow[t]{3}{*}{2} & $2 \mathrm{a}$ & + \\
\hline & $2 b$ & + \\
\hline & $2 \mathrm{c}$ & + \\
\hline 3 & & + \\
\hline \multirow[t]{2}{*}{4} & $4 a$ & + \\
\hline & $4 \mathrm{~b}$ & + \\
\hline \multirow[t]{2}{*}{5} & $5 a$ & + \\
\hline & $5 b$ & + \\
\hline 6 & &,+- \\
\hline 7 & & - \\
\hline 9 & & - \\
\hline 10 & &,+- \\
\hline 11 & & - \\
\hline 12 & & - \\
\hline 13 & & - \\
\hline 14 & & - \\
\hline
\end{tabular}

confirmed [17]. Some strains tested in this investigation, belonging to serogroups $\mathrm{O} 6$ and O10, were pathogenic while no strains belonging to serogroups O1c, O7, O9, O11, O12, $\mathrm{O} 13$ and $\mathrm{O} 14$ were severely pathogenic.

\section{DISCUSSION}

In this investigation, we showed that avirulent strains of $Y$. pseudotuberculosis exist. New strains serogrouped as O1c, O7, O9, O11, O12, O13 and O14 may be able to be classified as avirulent organisms when more strains of other serogroups have been tested for their pathogenicity.

We distinguished between pathogenic and less-pathogenic $Y$. pseudotuberculosis by the possession of pYV plasmid $[3-6,9,18]$ and the results of experimental infection of mice. Only a few strains belonging to O6 or O10 serogroups were positive in both tests and they can be considered as pathogenic. The pYV plasmid controls production of YOPs of Yersinia organisms. Loss of pYV plasmid or point mutation in the pYV plasmid results in decreased pathogenicity $[3-6,9,18]$. On the other hand, Miller et al. [15] reported that pathogenicity of Yersinia organisms is also encoded by chromosomal DNA. In fact, Shimonet et 
al. [20,21] observed that a strain of $Y$. pseudotuberculosis lacking pYV plasmid was able to multiply in tissues at the early stages of infection, similarly to strains harboring the pYV plasmid. Loss or mutation of the pYV plasmid induced a granulomatous response [22, 28]. Fukushima et al. [7] reported that $Y$. pseudotuberculosis $\mathrm{O} 4$ a lacking $\mathrm{pYV}$ was pathogenic and naturally infected humans. Thus, in Yersinia organisms, pathogenicity is governed by virulence factors encoded by chromosomal DNA and virulence factors of the pYV plasmid are linked to chromosome. Although pathogenicity of strains of $Y$. pseudotuberculosis lacking a pYV plasmid are attenuated, these are still enteropathogenic for mice because of the virulence factor encoded by chromosomal DNA. It is evident that invasiveness for epithelial cell is controlled by a virulence factor encoded by chromosomal DNA of Yersinia organisms. Nevertheless, non-pathogenic strains identified in this study are not enteropathogenic for mice. These observations suggest that pathogenicity of $Y$. pseudotuberculosis is governed by virulence factors other than invasive ability and the other factors are encoded by the pYV plasmid. In this study, it was shown that catalase activity of O1c, O7, O9, O11 and O12 strains is closely related to their ability to colonize the intestine. It is possible that non catalase producing bacteria are unable to multipling in vivo, therefore strains of $\mathrm{O} 13$ and $\mathrm{O} 14$ could not colonize the intestine and invade through mesenteric lymph nodes.

Pathogenicity of $Y$. enterocolitica is variable [2, 29-31] and pathogenic strains belong to limited serogroups and biogroups. Although non-pathogenic $Y$. pseudotuberculosis has not been recognized, non-pathogenic strains of $Y$. pseudotuberculosis are present in free-living animals and the environment. It is unclear why no non-pathogenic strain of $Y$. pseudotuberculosis has been recovered until now. Both non-pathogenicity and poor distribution make it difficult to isolate avirulent strains but a recent survey of Yersinia organisms proved their existence. The present results had new light on the study of ecology in Yersinia organisms.

ACKNOWLEDGMENTS. Authors are deeply grateful to Dr. Jane K. A. Cook for correction of the manuscript, Dr. T. Sanekata for technical assistance and Prof. T. Shinjo for valuable advice.

\section{REFERENCES}

1. Beers, R. F. Jr. and Sizer, I. W. 1952. A spectrophotometric method for measuring the breakdown of hydrogen peroxide by catalase. J. Biol. Chem. 195: 133-140.

2. Bottone, E. J. (ed.) 1981. Yersinia enterocolitica. CRC Press, Boca Raton, FL.

3. Brubaker, R. R. 1983. The $\mathrm{Vwa}^{+}$virulence factor of yersiniae: the molecular basis of the attendant nutritional requirement for $\mathrm{Ca}^{++}$. Rev. Infect. Dis. 5: S748-S758.

4. Butler, T. 1983. Plaque and other Yersinia infectious. Plenum Press, New York.

5. Cornelis, G., Laroche, Y., Balligand, G., Sory, M. P., and Wauters, G. 1987. Yersinia enterocolitica, a primary model for bacterial invasiveness. Rev. Infect. Dis. 9: 64-87.

6. Cornelis, G., Biot, T., Rouvroit, C. L., Michils, T., Mulder, B., Sluiters, C., Sory, M. -P., Bouchaute, M. V., and Vanooteghem, J. -C. 1989. The Yersinia yop regulon. Mol. Microbiol. 3: 1455-1459.

7. Fukushima, H., Sato, T., Nagasako, R., and Takeda, I. 1991. Acute mesenteric lymphadenitis due to Yersinia pseudotuberculosis lacking a virulence plasmid. J. Clin. Microbiol. 29: 1271-1275.

8. Higuchi, K. and Smith, J. L. 1961. Studies on the nutrition and physiology of Pasteurella pestis. IV. A differential plating medium for the estimation of the mutation rate to avirulence. J. Bacteriol. 81: 605-608.

9. Isberg, R. R., Voorhis, D. L., and Falkow, S. 1987. Identification of invasin: a protein that allows enteric bacteria to penetrate cultured mammalian cells. Cell 50: 769-778.

10. Kandolo, K. and Wauters, G. 1985. Pyrazinamidase activity in Yersinia enterocolitica and related organisms. J. Clin. Microbiol. 21: 980-982.

11. Kaneko, S., Maruyama, T., and Fukushima, H. 1991. Comparison of plasmid DNA among different serogroups of Yersinia pseudotuberculosis. Contrb. Microbiol. Immunol. 12: $75-79$.

12. Kauffmann, F. 1932/33. Vergleichende untersuchungen an Pseudotuberkulose-, Paratyphus-, Pasteurella- und Pestbacillen. Z. Hyg. Infektionskr. -Kr. 114: 97-105

13. Knapp, W. 1960. Uber weitere antigene Beziehungen zwischen Pasteurella pseudotuberculosis und der SalmonellaGruppe. Z. Hyg. Infektionskr. 146: 315-330.

14. Laird, W. J. and Cavanaugh, D. C. 1980. Correlation of autoagglutination and virulence in Yersiniae. J. Clin. Microbiol. 11: 430-432.

15. Miller, V. L., Finlay, B. B., and Falkow, S. 1988. Factors essential for the penetration of mammalian cells by Yersinia. Curr. Top. Microbiol. Immunol. 138: 15-39.

16. Nakajima, H., Inoue, M., Mori, T., Itoh, K., Arakawa, E., and Watanabe, H. 1992. Detection and identification of Yersinia pseudotuberculosis and Yersinia enterocolitica by an improved polymerase chain reaction method. J. Clin. Microbiol. 30: 2484-2486.

17. Regamey, R. H., Barbieri, A., Hennessen, W. de, Ikic, D. Perkins, F. T., and Ungar, J. (eds.). 1968. Symp. Series Immunobiol. Standard, vol. 9, Karger, Basel.

18. Rosqvist, R., Bolin, I., and Wolf-Watz, H. 1988. Inhibition of phagocytosis in Yersinia pseudotuberculosis: a virulence plasmid-encoded ability involving the Yop2b protein. Infect. Immun. 56: 2139-2143.

19. Schutze, H. 1928. Bacterium pseudotuberculosis rodentium. Rezeptorenanalyse von 18 Stammen. Arch. Hyg. (Berl.) 100: 181-194.

20. Simonet, M., Mazighd, M., and Berche, P. 1984. Growth of Yersinia pseudotuberculosis in mouse spleen despite loss of a virulence plasmid of mol. wt. $47 \times 10^{6} . J$. Med. Microbiol. 18: 371-375.

21. Simonet, M., Richard, S., and Berche, P. 1990. Electron microscopic evidence for in vivo extracellular localization of Yersinia pseudotuberculosis harboring the pYV plasmid. Infect. Immun. 58: 841-845.

22. Starley, S. C. and Cibull, M. L. 1989. Differential clearance and host-pathogen interactions of $\mathrm{YopE}^{-}$and $\mathrm{YopK}^{-} \mathrm{YopL}^{-}$ Yersinia pestis in BALB/c mice. Infect. Immun. 57: 12001210.

23. Thal, E. 1954. Untersuchungen uber Pasteurella pseudotu- 
berculosis. Lund, Sweden.

24. Tsubokura, M. and Aleksic, S. 1993. Characterization of Yersinia pseudotuberculosis serogroups O9, O10, O11; subdivision of serogroup into $\mathrm{O} 1 \mathrm{a}, \mathrm{O} 1 \mathrm{~b}$, and $\mathrm{O} 1 \mathrm{c}$ subgroups. Zbl. Bakt. 278: 500-509.

25. Tsubokura, M., Otsuki, K., Kawaoka, Y., and Maruyama, T. 1984. Characterization and pathogenic of Yersinia pseudotuberculosis isolated from swine and other animals. J. Clin. Microbiol. 19: 754-756.

26. Tsubokura, M., Otsuki, K., Kawaoka, Y., Fukushima, H., Ikemura, K., and Kanazawa, Y. 1984. Addition of new serogroups and improvement of the antigenic designs of Yersinia pseudotuberculosis. Curr. Microbiol. 11: 89-92

27. Tsubokura, M., Otuski, K., Sato, K., Tanaka, M., Hongo, T.,
Fukushima, H., Maruyama, T., and Inoue, M. 1989. Special features of distribution of Yersinia pseudotuberculosis in Japan. J. Clin. Microbiol. 27: 790-791.

28. Une, T. and Brubaker, R. R. 1984. In vivo comparison of avirulent $\mathrm{VWa}^{-}$and $\mathrm{Pgm}^{-}$or Pstr phenotypes of Yersiniae. Infect. Immun. 43: 895-900.

29. Wauters, G., Minor, L. L., and Chalon, A. M. 1971. Antigenes somatiques et flagellaires des Yersinia enterocolitica. Ann. Inst. Pasteur 120: 631-642.

30. Wauters, G., Minor, L. L, Chalon, A. M., and Lassen, J. 1972. Supplement au schema antigenique de (Yersinia enterocolitica). Ann. Inst. Pasteur 122: 951-956.

31. Winblad, S. (ed.). 1973. Yersinia, Pasterella, and Francisella. Contrib. Microbiol. Immunol., vol. 2, Karger, Basel. 